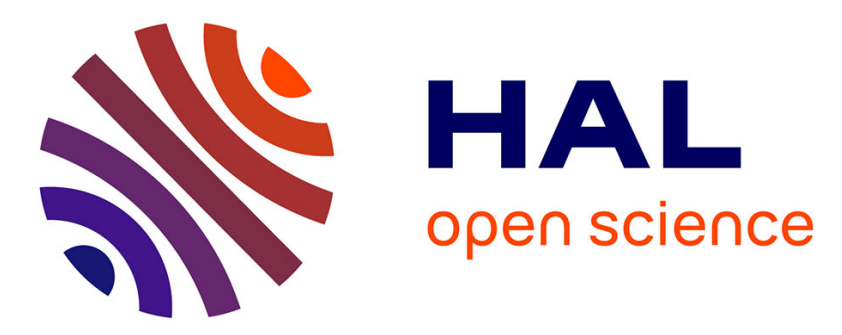

\title{
Physical modelling of chemical compaction, overpressure development, hydraulic fracturing and thrust detachments in organic-rich source rock
}

\author{
Alain Zanella, Peter Robert Cobbold, Christian Le Carlier de Veslud
}

\section{- To cite this version:}

Alain Zanella, Peter Robert Cobbold, Christian Le Carlier de Veslud. Physical modelling of chemical compaction, overpressure development, hydraulic fracturing and thrust detachments in organic-rich source rock. Marine and Petroleum Geology, 2014, 55, pp.262-274. 10.1016/j.marpetgeo.2013.12.017 . insu-01004020

\section{HAL Id: insu-01004020 \\ https://hal-insu.archives-ouvertes.fr/insu-01004020}

Submitted on 11 Jun 2014

HAL is a multi-disciplinary open access archive for the deposit and dissemination of scientific research documents, whether they are published or not. The documents may come from teaching and research institutions in France or abroad, or from public or private research centers.
L'archive ouverte pluridisciplinaire HAL, est destinée au dépôt et à la diffusion de documents scientifiques de niveau recherche, publiés ou non, émanant des établissements d'enseignement et de recherche français ou étrangers, des laboratoires publics ou privés. 


\title{
Physical modelling of chemical compaction, overpressure development, hydraulic fracturing and thrust detachments in organic-rich source rock.
}

\author{
A. Zanella*, P.R. Cobbold, C. Le Carlier de Veslud \\ Géosciences-Rennes (UMR-6118), CNRS and Université de Rennes 1, Campus de Beaulieu, \\ 35042 Rennes Cedex, France \\ *Corresponding author, e-mail: alain.zanella@univ-rennes1.fr
}

\begin{abstract}
Geological evidence for overpressure is common worldwide, especially in petroleum-rich sedimentary basins. As a result of an increasing emphasis on unconventional resources, new data are becoming available for source rocks. Abnormally high values of pore fluid pressure are especially common within mature source rock, probably as a result of chemical compaction and increases in volume during hydrocarbon generation. To investigate processes of chemical compaction, overpressure development and hydraulic fracturing, we have developed new techniques of physical modelling in a closed system. During the early stages of our work, we built and deformed models in a small rectangular box (40 x 40 x $10 \mathrm{~cm})$, which rested on an electric flatbed heater; but more recently, in order to accommodate large amounts of horizontal shortening, we used a wider box $(77$ x 75 x $10 \mathrm{~cm})$. Models consisted of horizontal layers of two materials: (1) a mixture of equal initial volumes of silica powder and beeswax micro-spheres, representing source rock, and (2) pure silica powder, representing overburden. By submerging these materials in water, we avoided the high surface tensions, which otherwise develop within pores containing both air and liquids. Also we were able to measure pore fluid pressure in a model well. During heating, the basal temperature of the model surpassed the melting point of beeswax $\left(\sim 62^{\circ} \mathrm{C}\right)$, reaching a maximum of $90{ }^{\circ} \mathrm{C}$. To investigate tectonic contexts of compression or extension, we used a piston to apply horizontal displacements.

In experiments where the piston was static, rapid melting led to vertical compaction of the source layer, under the weight of overburden, and to high fluid overpressure (lithostatic or greater). Cross-sections of the models, after cooling, revealed that molten wax had migrated through pore space and into open hydraulic fractures (sills). Most of these sills were
\end{abstract}


horizontal and their roofs bulged upwards, as far as the free surface, presumably in response to internal overpressure and loss of strength of the mixture. We also found that sills were less numerous towards the sides of the box, presumably as a result of boundary effects. In other experiments, in which the piston moved inward, causing compression of the model, sills also formed. However, these were thicker than in static models and some of them were subject to folding or faulting. For experiments, in which we imposed some horizontal shortening, before the wax had started to melt, fore-thrusts and back-thrusts developed across all of the layers near the piston, producing a high-angle prism. In contrast, as soon as the wax melted, overpressure developed within the source layer and a basal detachment appeared beneath it. As a result, thin-skinned thrusts propagated further into the model, producing a low-angle prism. In some experiments, bodies of wax formed imbricate zones within the source layer. Thus, in these experiments, it was the transformation, from solid wax to liquid wax, which led to chemical compaction, overpressure development and hydraulic fracturing, all within a closed system. According to the measurements of overpressure, load transfer was the main mechanism, but volume changes also contributed, producing supra-lithostatic overpressure and therefore tensile failure of the mixture.

Keywords: fluid overpressure, physical modelling, chemical compaction, thrust detachments

\section{Introduction}

Fluid overpressures are common worldwide, especially within petroleum-rich sedimentary basins (Swarbrick et al., 2002). Osborne and Swarbrick (1997) described three main mechanisms for the generation of fluid overpressures in sedimentary basins: diagenetic reactions, disequilibrium compaction and hydrocarbon generation. Several authors have described geological hydrofractures within source rocks for petroleum, these fractures having filled with solid materials, such as pyrobitumen or fibrous calcite. The solid infills have therefore preserved the fractures. Good examples come from the 'Vaca Muerta' source rock of the Neuquén Basin, western Argentina. In the northern part of this basin, bitumen veins are relatively common and tend to be parallel to bedding (Borrello, 1956; Abraham, 1960); whereas in the southern part, veins are commonly of fibrous calcite, but may also contain hydrocarbons (Parnell and Carey, 1995; Parnell et al., 2000; Rodrigues et al., 2009). In general, calcite veins that are parallel to bedding go under the name of "beef" (see historical and worldwide review by Cobbold et al., 2013). Cobbold and Rodrigues (2007) managed to 
reproduce open horizontal fractures in physical models, attributing them to the action of seepage forces, which result from vertical gradients in overpressure.

More generally, in the last decade or so, techniques of physical modelling have evolved, so as to take into account pore fluids and overpressures within granular materials and their structural effects (e.g. Cobbold and Castro, 1999; Cobbold et al., 2001; Mourgues and Cobbold, 2003; Cobbold and Rodrigues, 2007; Rodrigues et al. 2009). Other authors have used physical models to study processes of magmatic intrusion, especially during horizontal shortening (Benn et al., 1998; Galland et al. 2003, 2006, 2007; Gressier et al., 2012; RománBerdiel, 1999). However, in all of these physical models, the fluid pressures came from outside, via injectors. This technique has the advantage of allowing good controls on boundary conditions of pressure and flow rate, but it cannot investigate the causes of overpressure or the possible feedback between overpressure generation and hydrofracturing. For this purpose, Lemrabott and Cobbold (2010) developed another technique, in which model materials were of solid particles, of which some (beeswax microspheres) were able to melt, thus simulating the catagenesis of kerogen to hydrocarbons. The experiments resulted in fluid overpressure, partly as a result of volume changes (15\% for beeswax), but more as a result of load transfer, from the solid overburden to the pore fluid, during a process that was physically analogous to the chemical compaction of Swarbrick and Osborne (2002).

In what follows, we describe the results of similar experiments, but involving new apparatus and more detailed observations. We have studied the effects of overpressure development in various tectonic settings, in particular that of horizontal shortening, so as to simulate what happens to fold and thrust belts within foreland basins. A relevant example is the Magellan (Magallanes-Austral) Basin of southern Patagonia, South America, where detachments have occurred within source rock (Diraison et al., 1997; Cobbold, 2005; Rojas and Mpodozis, 2006; Zanella et al., in press).

\section{Experimental Materials}

In all of our physical models, the scaling was such that $1 \mathrm{~cm}$ in the model represented something between $100 \mathrm{~m}$ and $1 \mathrm{~km}$ in nature. To model brittle rock, we therefore used weak frictional material, which failed according to a Mohr-Coulomb envelope. However, we required two such materials, one representing a source rock, the other representing an overburden of low permeability. 
As an analogue material for the overburden, we used a pure silica powder (Millisil C4, available from Sifraco, Compiègne, France). This material has a grain size of less than 150 $\mu \mathrm{m}$, a porosity of about $40 \%$, a bulk density of about $1.34 \mathrm{~g} / \mathrm{cm}^{3}$ and an intrinsic permeability of about 1.6 Darcy (Table 1B; see also Rodrigues et al., 2009, their table 2A). Because the grains are angular, they tend to lock together, so that the dry material is cohesive. It fails according to a Coulomb criterion, the cohesive strength being about $300 \mathrm{~Pa}$ and the angle of internal friction about $40^{\circ}$ (see Galland et al., 2006; their table 1B). In tension, the material has a strength of about $100 \mathrm{~Pa}$ and fails by forming open fractures. However, in our experiments, we saturated the silica powder with water, by fully submerging it. Thus we avoided the high surface tensions, which otherwise develop within pores that simultaneously contain air and one or more liquids, rendering the material cohesive (as in sand castles on a beach). As yet, we have not measured the mechanical properties of the silica powder in an underwater state. However, Graveleau et al. (2011, table 1B) have done so, for a similar silica powder. In their tests, capillary cohesion was absent or very small and the behaviour of the water-saturated material was analogous to that when it was dry. Currently, we are developing new techniques for measuring the mechanical properties of silica powder or similar materials, when fully under water.

For the source rock, following Lemrabott and Cobbold (2010), we used a mixture of silica powder and beeswax microspheres (Table 1). The microspheres (about $1 \mathrm{~mm}$ in diameter) are readily available in France for making candles and pharmaceutical products. The variety that we used (cire d'abeille blanche en microbilles, from La Marchande de Couleurs) is solid at room temperature, but melts at $62-64{ }^{\circ} \mathrm{C}$ to a liquid of low viscosity $(14 \mathrm{x}$ $10^{-3} \mathrm{~Pa} \mathrm{~s}$, Table 1B). The density of the solid beeswax is $0.95 \mathrm{~g} / \mathrm{cm}^{3}$ and the density of the melt is $0.82 \mathrm{~g} / \mathrm{cm}^{3}$ at $80^{\circ} \mathrm{C}$. Melting therefore implies a decrease in density and an increase in volume. The coefficient of linear expansion is $350 \times 10^{-6} /{ }^{\circ} \mathrm{C}$, corresponding to a volume change of no more than $15 \%$ or so (similar to that for catagenesis of kerogen to oil). These properties mean that the beeswax is a useful analogue material for organic matter in sediment. For the mixture, we used equal initial volumes of beeswax and of silica powder. However, the initial porosity of the beeswax powder was about $40 \%$ and the microspheres were much larger than the particles of silica, so that, on mixing the two materials, much of the silica occupied the original pore space between the microspheres. Thus the volume percentage of beeswax in the final mixture was about $40 \%$.

\section{First experiments (Series I)}




\subsection{Apparatus and experimental procedure}

During the early stages of our work on the development of fluid overpressures, we built our models in a small apparatus, similar to that of Lemrabott and Cobbold (2010). It consisted mainly of a rectangular plastic box, $30 \mathrm{~cm}$ long, $20 \mathrm{~cm}$ wide and $10 \mathrm{~cm}$ high (Fig. 1). The aim was to heat the model from the base, until the temperature of the beeswax exceeded its melting point $\left(\sim 62-64^{\circ} \mathrm{C}\right)$. The baseplate of the box was therefore of aluminium, to facilitate transfer of heat, whereas the sidewalls were of transparent plastic, for better observation and thermal insulation (Fig. 1). The box rested on a flatbed electric heater, which was able to deliver a maximum power of $1 \mathrm{~W} / \mathrm{m}^{2}$. In our experiments, we used only $30 \%$ of this power, in order to reach a maximum temperature of $90{ }^{\circ} \mathrm{C}$. To investigate the influence of tectonic compression or extension, we used a piston to apply horizontal displacements.

We built each model in three layers. The two basal layers, each $1 \mathrm{~cm}$ thick, consisted of a mixture of coloured silica powder (blue or yellow) and beeswax microspheres, whereas the overlying third layer, $1.5 \mathrm{~cm}$ thick, was of pure silica powder. We deposited each layer carefully and then scraped its surface flat. Thereby, the total thickness of the model was 3.5 $\mathrm{cm}$. Finally we submerged the model, by slowly pouring water onto its surface, in one corner of the box, until the water level was $1 \mathrm{~cm}$ above the top of the third layer. Before heating or deforming the model, we waited for several hours, so that any air bubbles would have time to rise to the surface.

During each experiment, we used several vertical wells (glass tubes), to measure the pore fluid pressure at depth. In fact, we recorded the hydraulic head (difference in water level, inside and outside the tubes). The tubes were at the sides of the models, in order to minimize disturbances (which might have triggered horizontal hydraulic fractures). We also plugged the bottom of each tube with a piece of metallic mesh, to prevent any solid particles from penetrating it. Temperatures were recorded (with a precision of $\pm 0.1^{\circ} \mathrm{C}$ ) by transducers or thermocouples in three positions: (1) the heater itself, (2) within the aluminium plate and (3) at the base of the model.

After each experiment, we drained the model and left it for one night to dry on a hot plate at $50{ }^{\circ} \mathrm{C}$. Then, before cutting the model, we impregnated it with gelatine solution and dried it again. With a knife we then cut cross-sections every $2 \mathrm{~cm}$. This technique has the advantage of preserving the slices for long periods of time.

\subsection{Results of Experiments}


With this first apparatus we did 11 experiments. The results were consistent and here we will describe four representative examples (Fig. 2).

\subsubsection{Experiment 1 (containing 'organic matter', but with no overall tectonic} deformation)

In Experiment 1 (Fig. 2B) the lower two layers contained beeswax and the boundaries were static, so that the model did not change shape externally. During heating, the temperature rose over a period of 400 minutes to a maximum of $74{ }^{\circ} \mathrm{C}$ at the base of the model. By also measuring the temperature at the surface of the model, we deduced a vertical thermal gradient of $10{ }^{\circ} \mathrm{C} / \mathrm{cm}$ at the centre of the model. Some $80 \mathrm{~min}$ after the temperature at the base surpassed the melting point of wax $\left(\sim 62-64{ }^{\circ} \mathrm{C}\right)$, the hydrostatic head (difference in water level, inside and outside the glass tube) began to increase. After another 3 hours or so, the hydrostatic head had reached a value of $12 \mathrm{~mm}$. This was comparable to the vertical stress, due to the weight of overburden and source layers, at the base of the model. Indeed, if we assume for the granular material an average density (when dry) of $1.3 \mathrm{~g} / \mathrm{cm}^{3}$, subtract the density of water $\left(1 \mathrm{~g} / \mathrm{cm}^{3}\right)$, to account for buoyancy, then take a total thickness of $3.5 \mathrm{~cm}$, this yields a vertical stress of $10.5 \mathrm{~g} / \mathrm{cm}^{2}$ (about $100 \mathrm{~Pa}$ ), which is equivalent to the weight of 10 $\mathrm{mm}$ of water. We therefore infer that melting produced an approximately lithostatic overpressure at the base of the model. Indeed, cross-sections (Fig. 2B) showed horizontal bodies (sills) of wax, which formed by horizontal hydraulic fracturing within the yellow layer. In addition, by this stage the blue layer had become thinner than the yellow layer, although originally the thicknesses of the two layers were the same. This thinning (compaction) of the blue layer was thus due to loss of beeswax by melting and upward migration.

\subsubsection{Experiment 11 (no 'organic matter' and no 'tectonic' deformation)}

Here the conditions were the same as in Experiment 1, except that there was no wax in either of the two basal layers (Fig. 2A). The temperature rose in a similar way, but the water level in the glass tube remained steady ( $2 \mathrm{~mm}$ of hydrostatic head). We suspect that this small value may have been due to a wax plug at the base of the tube. On cross-sections (Fig. 2A), no internal structures were visible and the thicknesses of the various layers did not change.

\subsubsection{Experiment 4 ('organic matter' and extensional deformation)}

In Experiment 4 (Fig. 2C), we used a piston to induce horizontal extension. The piston velocity was $2.5 \mathrm{~cm} / \mathrm{h}$. We decided to start it moving only after the wax had begun to melt, to 
see if extension might have an effect on fluid overpressure. We heated the model as in both previous experiments. Just after the wax began to melt, the hydrostatic head started to increase within the glass tube. When extension began, the hydrostatic head continued to increase, but more slowly than in Experiment 1. On cross-sections (Fig. 2C), various structures were visible. Near the piston there were several wax dykes, steeply dipping or vertical, whereas away from the piston there were some small sills (a few mm long) at the base of the yellow layer.

\subsubsection{Experiment 8 ('organic matter' and compressional deformation)}

For Experiment 8 we used the piston to apply horizontal shortening at a velocity of 2.5 $\mathrm{cm} / \mathrm{h}$ (Fig. 2D). As in the previous two experiments, melting of the wax led to a hydrostatic head, which we attribute to fluid overpressure at the base of the model. However, when horizontal compressional started, the hydrostatic head rose at a rate that was faster than in the previous experiments, to a value of $23 \mathrm{~mm}$. Thus we infer that shortening contributed to overpressure, perhaps via horizontal tectonic compaction. The cross-sections (Fig. 2D) show that sills of wax became thicker and longer than those in Experiment 1 (involving no 'tectonic' deformation). Moreover, the sills were subject to folding and reverse faulting, especially near the piston. The blue layer became slightly thinner than the yellow layer, as a result of compaction.

\subsection{Conclusions for first experiments}

From the first four experiments (Series I), we infer that it was the transformation from solid to liquid wax that resulted in fluid overpressure and horizontal hydraulic fracturing. Indeed, such overpressure arose when there were source layers in the model (Figs. 2B, 2C, 2D), but not when source layers were absent (Fig. 2A). Because the volume change, from solid to liquid wax, was no more than about $15 \%$, we attribute the overpressure to a mechanism of load transfer, from the overburden to the pore fluid, as the solid framework collapsed and compacted. The molten wax migrated through pore space and into open hydraulic fractures, where it solidified, when the temperature was low enough. Compressional deformation had an amplifying effect on this process (Experiment 8, Fig. 2D) and produced more complex structures (folds and faults) around the hydrofractures.

\section{New experiments (Series II)}


Although the results for the first apparatus were encouraging, we did observe some edge effects along the transparent sidewalls, especially when the piston advanced, producing compressional deformation. These effects we attribute to high friction against the sidewalls. In order to avoid this and to be able to model larger amounts of horizontal deformation, we decided to build a longer and wider box (Fig. 1).

\subsection{Apparatus and experimental procedure}

The new apparatus consists of a square box, $1 \mathrm{~m}$ wide and $10 \mathrm{~cm}$ high, resting on an aluminium table (Fig. 1B). The size of the model is $77 \times 75 \mathrm{~cm}$ (dimensions of the internal box, Fig. 1C). For such a large box, we were unable to find a single electric heater that was powerful enough. Instead, we mounted one circular heating plate $(15 \mathrm{~cm}$ in diameter) beneath the centre of the model and two identical rectangular plates, $75 \mathrm{~cm}$ long and $37.5 \mathrm{~cm}$ wide, beneath each half of the model. Each of these heating plates can deliver $1 \mathrm{~W} / \mathrm{m}^{2}$, as in the first apparatus, and has its own electrical control system, incorporating several thermocouples.

As before, we built the models with two source layers $(1 \mathrm{~cm}$ thick) and one overlying layer of pure silica powder $(1.5 \mathrm{~cm}$ thick). In all the experiments, the models were under water. For details of construction, see part 2.1. In one experiment, where a piston was to cause horizontal shortening of the model, we added a basal black layer of quartz sand (e.g. Fig. 9B) and strips of pure silica powder at the sides of the mode. Because the black sand contained no wax, heating did not lead to an internal increase in fluid overpressure and therefore the frictional resistance of the material remained high. In contrast, along the sides of the model, the frictional resistance of the silica powder, when under water, was much lower than that of the mixture of sand and beeswax microspheres. Because the models were so large, we did not impregnate them with a gelatine solution. Instead, we wet them with water, cut serial crosssections (every $2 \mathrm{~cm}$ ) with a knife, and made a panoramic image of each section, using a sequence of overlapping photographs (Fig. 4; Fig. 9).

As before, we used vertical wells, to measure the pressure in the model. To record the temperature, we used thermocouples, but in three positions at the base of the model: (1) at the centre; (2) at $20 \mathrm{~cm}$ from the edge; and (3) at the edge. The aim was to check for horizontal thermal gradients during the experiments.

\subsection{Results of Experiments}

So far, we have done 8 experiments with this new apparatus, under conditions of (1) no 'tectonic' deformation or (2) horizontal shortening (compressional deformation). In what 
follows, we will describe one example from each context, giving particular attention to Experiment 4, for which we used a gOcad 3D modeller to define the shapes of layers and wax bodies.

\subsubsection{No tectonic deformation}

Of the experiments that we did under static conditions (no applied horizontal deformation), Experiment 4 was the one that yielded the most data. To estimate the pore fluid pressure, we recorded the hydrostatic head in five wells, which penetrated both source layers to different depths (every $0.5 \mathrm{~cm}$, from the base to the top; Fig. 3). To record the temperature, we placed thermocouples at 3 different horizontal positions along the base of the model. About 200 minutes from the beginning of heating, a central bulge appeared at the surface. The visibility was even greater after drying the model, because this avoided the optical distortions due to the water, which initially covered the model. Surrounding the central bulge was a local depression of the top surface (Fig. 3B). Other bulges, similar in shape but smaller, formed a circular pattern around the centre of the model, at about $20 \mathrm{~cm}$ from its edges. These structures were discernable, in part at the surface, but more so on cross-sections and in the 3D model (Figs. 6 and 7). Also visible at the surface were some shallow runnels, which formed during the progressive wetting of the model (Fig. 3). However, these did not have any effects at depth.

The temperature data revealed a horizontal thermal gradient within the model, which stabilised at about $0.6^{\circ} \mathrm{C} / \mathrm{cm}$ during much of the experiment. We attribute this gradient to loss of heat by conduction through the sidewalls of the box and/or radiation from their outer surfaces. After melting of the wax, the hydrostatic heads in the glass tubes increased (to 2 $\mathrm{mm}$ ), but then they appeared to stop. We suspect that this may have been due to wax, which penetrated the tubes when molten and then solidified.

At the end of the experiment, serial cross-sections of the entire model (every $2 \mathrm{~cm}$ ) revealed many sills of wax (white, Fig. 4). The thickest and widest formed in the yellow source layer, in the central part of the model, but thinner and smaller sills formed in both the blue and yellow layers.

Another change was in the thickness of the basal blue layer. A wide depression formed at the centre of the model, beneath the main wax sill. Local irregularities in the thickness of the yellow layer also developed, but mainly during submerging of the model, when water penetrated the mixture of silica powder and beeswax microspheres. 


\subsubsection{3D Reconstruction of model, Experiment 4}

The cross-sections yielded only sparse information on the three-dimensional shapes of layers and wax bodies. Unfortunately, on trying to cut sections at a closer spacing, we found that the intervening slabs tended to deform. Thus, for Experiment 4 (which involved no overall horizontal shortening), we decided instead to use a numerical method (gOcad 3D geomodeller; Mallet, 2002), to reconstruct the shapes of the layer interfaces and to calculate the volumes of wax bodies and layers (see Appendix for method).

According to the results of this gOcad modelling, the layers developed topographic bulges and depressions, which formed a broadly axisymmetric pattern about the centre of the model. We attribute this pattern to the thermal gradient, acting horizontally across the model. The upper surface of layer L1 (5A) had a central depression ( $20 \mathrm{~cm}$ wide, $2 \mathrm{~mm}$ deep) and a surrounding ring of minor bulges ( $2 \mathrm{~mm}$ high); whereas the upper surfaces of layers L2 (Fig. 5B) and L3 (Fig. 5C) had central bulges (13 cm wide, $9 \mathrm{~mm}$ high), as well as surrounding inner rings of depressions ( $2 \mathrm{~mm}$ deep) and outer rings of bulges ( $2 \mathrm{~mm}$ high).

Sectioning and 3D modelling also revealed a large number of wax bodies in the model. About 750 of these bodies were small (only a few mm wide), whereas about 65 of them were larger (more than $10 \mathrm{~mm}$ wide) and had shapes like magmatic sills. The latter formed only in layers L1 and L2. In L1, a few sills were at the base, reflecting local melting, but most of them were close to the top. Some of them developed within L1, inducing bulges at the top of that layer. Other sills were larger and developed, partly at the top of L1, but more so within L2. Beneath them depressions formed (at the top of L1), whereas above them bulges formed (at the tops of both L2 and L3). This was particularly true in the centre of the model, where a large wax body (130 x 150 × 20 mm; Fig. 6) developed.

\subsubsection{Calculation of volumes}

The layers in the model underwent changes in volume (Table 2A), as a result of two main processes: (1) vertical compaction, during submersion under water, and (2) migration and intrusion of wax and consequent deformation.

For layer L3, which contained no original wax microspheres and was not subjet to intrusion by wax, the volume change (ca. 20\%, Table 2A) was due to compaction during wetting. In contrast, for each of layers L1 and L2, volume changes were due to compaction, intrusion, or both. However, on considering both layers (L1 and L2) together, the wax remained within the system. Thus the overall volume change was due to compaction only. However its value (1.4\%, Table 2A) was significantly smaller than for layer L3. A possible 
explanation is that the density of the wax $\left(\mathrm{ca} .0 .95 \mathrm{~g} / \mathrm{cm}^{3}\right)$ was smaller than that of water, so that its buoyancy impeded compaction.

On removing the effects of compaction from layers L1 and L2 (assuming an even distribution within each layer), it is possible to estimate the volume changes, due to migration and intrusion of wax. According to the results, layer L1 lost about $500 \mathrm{~cm}^{3}$ of wax, whereas L2 gained the same amount (Table 2B). Alternatively, 3D modelling, using the gOcad 3D modeller, yields the total volumes of wax bodies in each layer (Table 2C). We have investigated two such 3D models, which assume different degrees of connectivity between cross-sections (see Appendix). The first model, which assumes no connectivity, yields a total volume of $500 \mathrm{~cm}^{3}\left(215 \mathrm{~cm}^{3}\right.$ in L1 and $285 \mathrm{~cm}^{3}$ in L2); whereas the second model, which assumes connectivity, yields a larger total volume of $810 \mathrm{~cm}^{3}\left(380 \mathrm{~cm}^{3}\right.$ in L1 and $430 \mathrm{~cm}^{3}$ in L2). The difference in results between the two models reflects the difficulty of reconstructing complex objects from cross-sections alone. Taking into account the uncertainties in calculating volumes (ca. $150 \mathrm{~cm}^{3}$, see Appendix), the volumes of wax bodies for both models (Table 2C) are comparable to the volume changes estimated from the gOcad modelling for layers L1 and L2 (Table 2B).

Finally, amongst the wax bodies, we may distinguish those that we consider as "intrusive" from those that were not. Most of the small wax bodies developed within L1 resulted from in-situ melting of one or more microspheres and were therefore not intrusive. In contrast, larger bodies resulted from migration of molten wax. Conservatively, we consider as intrusive those wax bodies that traversed the interface between the two layers, L1 and L2, or those in L1 that led to bulging at the top of the layer. We have chosen not to list or illustrate these intrusive bodies, because they number as many as 100 . However, on taking them into account, Model 2, which assumes connectivity between the wax bodies visible in the sections and thereby predicts a total intrusive volume of $550 \pm 50 \mathrm{~cm}^{3}$ (Table 2C), would appear to be more realistic than Model 1.

\subsubsection{Interpretation}

Wax bodies within layer L1 produced overlying bulges, which were visible at the end of the experiment. In contrast, bodies that developed within both layers (L1 and L2) produced depressions at the top of L1 and bulges at the top of L2, these structures resulting from intrusion. For L2, the similarity (within the range of uncertainty), between (1) the volume change of the entire layer and (2) the volumes of wax bodies, supports the idea that those bodies were mainly intrusive and that they derived from the melting of wax in layer L1 
(where the temperature was hotter) and its subsequent migration. This happened especially, but not only, in the centre of the model. Local intrusion resulted in deflation of layer L1 (and a resulting depression at its top), together with inflation of layer L2 (and a bulge at its top), as previously mentioned.

Finally, from the results it is possible to derive the fraction of melt. Assuming (1) a volume of intrusion of $550 \pm 50 \mathrm{~cm}^{3}$, (2) that this originated mainly in layer L1, (3) an initial porosity of $30 \%$ for layer L1 (neglecting compaction), and (4) an initial wax content of $50 \%$ for layer L1, we calculate that the melt fraction was between 25 and $30 \%$. However, because it is likely that some of the intrusive wax originated also in layer L2, a melt fraction of $25 \%$ would appear to be more realistic.

\subsubsection{Compressional deformation}

In Experiment 5 (Series II), a piston caused horizontal shortening of the model. This was the first experiment of the kind that we performed in the large box. So as not to disturb the model, we avoided using vertical wells to measure the pore fluid pressure. The aim of the experiment was to observe the effects of the generation of overpressure in a source material on the development of folds and thrusts. Thus we activated the piston at the beginning of heating. During the first hour of the experiment, the temperature at the base of the model did not exceed the melting point of wax $\left(\sim 62-64^{\circ} \mathrm{C}\right)$ and shortening resulted in the formation of a high-angle wedge (next to the piston), which contained a series of fore thrusts and a single back thrust (Fig. 7B). At this stage, the structures had relatively straight traces. However, after one hour of experiment, once melting had occurred, the style of deformation began to change. In the central part of the model, the deformation front migrated very quickly, away from the piston, and it also began to curve. By the end of the experiment (after 170 minutes), the curvature was greater than one might expect as a result of boundary friction alone (Fig. 7C).

After deformation, serial cross-sections of the model revealed that the high-angle wedge, which had formed near the piston during the earliest stages of the experiment, was thickskinned, in the sense that it involved all the layers in the model, including the basal layer of black sand (Fig. 8). The wedge contained a major back thrust and several steep fore thrusts. Toward the centre of the model, thrusts were less steep. They were also thin-skinned, in that they affected, not so much the basal black layer, as the source layers (yellow and blue) or the overburden (white). The gently dipping thrusts detached at the base of the yellow source layer (Fig. 8). Within that same layer, some small gently dipping wax lenses appeared (Fig. 8 and 
Fig. 10). We infer that they formed by hydraulic fracturing during thrust development (top to right, Fig. 10). These results were reproducible.

\subsection{Conclusions for experiments in the large apparatus (Series II)}

In the larger apparatus, edge effects were less widespread than they were in the smaller apparatus. Furthermore, the deformation was easier to study. However, wax bodies formed widely throughout the models. As for the experiments in the smaller apparatus, we infer that the melting of wax (and so the generation of more liquid) led to load transfer from the solid framework to the pore fluid. Under the resulting overpressure gradient, the wax migrated through pore space. Some of it filled the horizontal hydraulic fractures, as they opened. Then the wax solidified, upon cooling. In Experiment 4 (no applied horizontal deformation), the horizontal hydraulic fractures clearly opened in tensile mode, locally uplifting parts of the blue source layer (Fig. 10A).

The gOcad 3-D geomodeller allowed us to define shapes and to estimate volumes, on the basis of sections alone. It therefore helped us to understand (1) the migration of fluid from areas of generation to 'reservoirs' and (2) the distribution of compaction. In our experiments, wax appeared to have migrated from the basal warmest area, at the centre of the model, to colder areas above and at the sides. Thus the 3D model has revealed both vertical and lateral migration of wax.

In experiments where a piston caused horizontal shortening (compressional deformation) of a model, the deformation was thick-skinned before the melting of wax, but changed to thinskinned during the melting of wax and the development of fluid overpressure. Thrusts propagated into the model by detaching at the base of the source layers and the deformation front became strongly curved (Fig. 10B). We infer that detachment was easier in the centre of the model, because there the temperatures were higher and so was the overpressure.

\section{Discussion}

Most previous physical modelling of the structural effects of overpressure in sedimentary basins made use of external fluid injectors (Cobbold et al., 2001; Mourgues and Cobbold, 2003; Cobbold and Rodrigues, 2007). In contrast, in our experiments, an overpressured fluid arose by transformation from a solid to a liquid phase (in fact, by melting). For this purpose, following Lemrabott and Cobbold (2010), we used microspheres of beeswax. 
In all experiments where source layers were present, we observed the development of fluid overpressure and hydraulic fracturing within them. In contrast, when no source layers were present, no fluid overpressure or hydraulic fractures developed. In other words, it was the production of liquid wax (from solid wax), which led to the generation of fluid overpressure and hydraulic fracturing in our models. During melting, the volume change did not exceed $15 \%$ and this was not enough to explain the supra-lithostatic overpressure. However, the melting led to collapse of the solid load-supporting framework and therefore, inevitably, to load transfer from the overburden to the fluid, this process being mechanically analogous to chemical compaction (Swarbrick and Osborne, 2002). Finally, the overpressure gradient was enough to initiate hydraulic fractures, which filled with liquid wax.

In those experiments, for which we also imposed a compressional deformation, some hydraulic fractures formed and filled with molten wax. However, the main features were faults. Before any overpressure developed, the deformation was thick-skinned and produced a high-angle wedge, containing forethrusts and backthrusts; whereas, when melting started, the deformation became thin-skinned, above detachments in the source layers (and not the underlying black layer), leading to the formation of a low-angle wedge. Analogous features are visible in the Magallanes-Austral Basin, where Zanella et al. (in press) have found bedding-parallel veins of fibrous calcite (beef), due to hydraulic fracturing, as well as thrust detachments, all within mature source rock of Early Cretaceous age, lying upon Jurassic volcanic rocks or Palaeozoic basement.

In the future, we anticipate that it will useful to model what happens in other tectonic contexts (such as strike-slip). It will also be important to study in more detail the mechanical properties of the various materials used in the experiments, especially when the amount of pore fluid increases and intrusion becomes significant.

\section{Conclusions}

In sedimentary basins worldwide, abnormally high values of pore fluid pressure are common within mature source rock. This phenomenon is probably the result of chemical compaction and increases in volume during hydrocarbon generation. To investigate processes of chemical compaction, overpressure development and hydraulic fracturing, we have used physical models, which are able to generate a fluid from solid particles (beeswax microspheres) within a closed system. In our experiments, it was the transformation, from solid wax to liquid wax, which led to internal compaction, overpressure development and 
hydraulic fracturing, all within a physical model of a source rock. In experiments where the piston was static, rapid melting led to vertical compaction of the source layer, under the weight of overburden, and to high fluid overpressure (lithostatic or greater). Cross-sections of the models, after cooling, revealed that molten wax had migrated through pore space and into open hydraulic fractures (sills). Under conditions of horizontal shortening and compressional deformation, sills also formed. However, these were thicker than in static models and some of them were subject to folding or faulting. For experiments, in which horizontal shortening started, before the wax had melted, overpressure development had a large effect on the style and speed of propagation of thrusting, which changed from thick-skinned to thin-skinned, above detachments within the source layers. According to our measurements of overpressure, load transfer was the main mechanism of overpressure development, but volume changes also contributed, producing supra-lithostatic overpressure and therefore tensile failure of the mixture.

\section{Acknowledgements}

We are grateful to Statoil for funding the $\mathrm{PhD}$ project of Alain Zanella. Jean-Jacques Kermarrec, Ingénieur d'études au CNRS, and Pascal Roland, technician at the University of Rennes 1, helped to build the first apparatus. Alain Zanella thanks the engineers and technicians of the Centre Commun de Mécanique, Institut National des Sciences Appliquées (INSA) de Rennes, especially Patrick Weber, for their professional and technical help in designing and building the new apparatus.

\section{Appendix: gOcad 3D modelling}

\section{The gOcad 3D modeller and the available data}

We used the gOcad 3D numerical modeller (Mallet, 2002) to reconstruct the shapes of layer boundaries and to estimate the volumes of intrusive bodies and layers. GOcad modelling is a purely geometrical form of computer-assisted design, which provides a discrete representation of geological objects in terms of regular meshes (grids) or irregular meshes (polygonal curves, triangulated surfaces, or tetrahedralized solids; Mallet, 2002). Triangulated surfaces appeared to be particularly relevant for representing closed surfaces, such as those of the wax bodies. The 3D reconstruction of geological structures from the data is by Discrete Smooth Interpolation (DSI; Mallet, 1992; 2002). 
For our purposes, we digitized the contours of objects on the 29 cross sections of Experiment 4, imported the data into gOcad and removed the optical distortions that were due to photography. Cross-sections lie in the $\mathrm{X}-\mathrm{Z}$ plane, so that the $\mathrm{Y}$ axis is normal to them. The modelling yielded two kinds of polygonal lines, (1) open lines, representing the interfaces between the main layers, and (2) closed lines, representing molten wax bodies.

\section{$3 D$ modelling process}

Reconstructing a surface from cross-sections alone is a common need, for example in geological or bio-medical imaging (Boissonnat and Memari, 2007; Liu et al., 2008). When building 3D objects from 2D sections, two potential problems arise. First, the sections imply data anisotropy, more information being available along the sections than transversely. To reduce this problem, we smoothed the data and this implied a choice of smoothing parameters. Second, the reconstruction of 3D shapes from cross-sections requires correlation from one section to another. This is more difficult for bodies that are small, in comparison with the spacing of sections (the "cut section effects" of Higgins, 2000). The dimensions of the bodies, as visible on sections, may not be representative of their true sizes in three dimensions and the sections are more likely to intersect small bodies than large ones, because the latter are more numerous. Therefore, we adopted the following procedure.

1. To reconstruct the layer boundaries, we used Discrete Smooth Interpolation, so obtaining continuous triangulated surfaces from the sections.

2. For the wax bodies, we used an implicit method (Frank et al., 2007), which is robust and able to handle arbitrary shapes (e.g. holes or bifurcations). An implicit method reconstructs a surface from an equipotential of a 3D implicit scalar function. In general, this function is obtained from the data by interpolation on a 3D grid (see review by Frank et al., 2007). In our application of this method, we interpolated the implicit function on a 3-D grid with corner-point hexahedral cells, using the DSI method. Then, we extracted triangulated surfaces, corresponding to wax bodies, as isovalues of the 3D grid. Because hexahedral grids have limited adaptativity, we improved the fit of the obtained surfaces to the wax contours, using the DSI method.

3. In order to estimate the degree of connection of the wax bodies, we tried 2 end-member models, using implicit methods. The first model reconstructs only the largest wax bodies, for which connections are clear. For small bodies the model estimates volumes, assuming that they are separate ellipsoids. This first model clearly underestimates the total volume of wax bodies. Thus we tried a second model, which includes contours for all wax bodies. 
This model tends to result in more connections between small bodies and therefore yields a larger estimate for the total volume of wax bodies.

\section{References}

Abraham, H., 1960. Asphalt and allied substances. Volume 1, Sixth Edition, D. Van Nostrand Company, New York, U.S.A., 325 pages.

Benn, K., Odonne, F., Saint Blanquat, M. de, 1998. Pluton emplacement during transpression in brittle crust: new views from analogue experiments. Geology, 26, 1079-1082.

Boissonnat, J.D., Memari, P., 2007. Shape reconstruction from unorganized cross-sections. In SGP '07: Proceedings of the fifth Eurographics symposium on Geometry processing, 8998.

Borrello, A.V., 1956. Recursos minerales de la República Argentina. III. Combustibles sólidos minerales. Revista del Instituto Nacional de Investigación de las Ciencias Naturales, Ciencias Geológicas 5, 665 pp.

Cobbold, P.R., 2005. Hydrocarbon generation, fluid overpressure and source rock detachments in thrust belts. Thrust Tectonics 99, Egham, Extended Abstracts, p. 7-9.

Cobbold, P.R., Castro, L., 1999. Fluid pressure and effective stress in sandbox models. Tectonophysics 301, 1-19.

Cobbold, P.R., Durand, S., Mourgues, R., 2001. Sandbox modelling of thrust wedges with fluid-assisted detachments. Tectonophysics 334, 245-258.

Cobbold, P.R., Rodrigues, N. 2007. Seepage forces, important factors in the formation of horizontal hydraulic fractures and bedding-parallel fibrous veins ("beef" and "cone-incone”). Geofluids 7, 313-332, doi:10.1111/j.1468-8123.2007.00183.x.

Cobbold, P.R., Zanella, A., Rodrigues, N., Løseth, H. 2013. Bedding-parallel fibrous veins (beef and cone-in-cone): worldwide occurrence and possible significance in terms of fluid overpressure, hydrocarbon generation and mineralization. Marine and Petroleum Geology 43, 1-20, doi: 10.1016/j.marpetgeo.2013.01.010.

Diraison, M., Cobbold, P.R., Gapais, D., Rossello, E.A., Gutiérrez Pleimling, A., 1997. Neogene tectonics within the Magellan basin (Patagonia). VI Simposio Bolivariano, 
Petroleum exploration in the Subandean basins, Cartagena de Indias, Colombia, Memorias, Tomo 1, 1-14.

Galland, O., de Bremond d'Ars, J., Cobbold, P.R., Hallot, E., 2003. Physical models of magmatic intrusion during thrusting. Terra Nova 15, 405-409.

Galland, O., Cobbold, P.R., Hallot, E., de Bremond d'Ars, J., Delavaud, G., 2006. Use of vegetable oil and silica powder for scale modelling of magmatic intrusion in a deforming brittle crust. Earth and Planetary Science Letters 243, 786-804.

Galland, O., Cobbold, P.R., de Bremond d'Ars, J., Hallot, E., 2007. Rise and emplacement of magma during horizontal shortening of the brittle crust: insights from experimental modeling. Journal of Geophysical Research 112, B06402.

Graveleau, F., Hurtrez, J.E., Dominguez, S., Malavieille, J., 2011. A new experimental material for modeling relief dynamics and interactions between tectonics and surface processes. Tectonophysics 513, 68-87.

Gressier, J. B., Mourgues, R., Bodet, L., Matthieu, J. Y., Galland, O., Cobbold, P., 2010. Control of pore fluid pressure on depth of emplacement of magmatic sills: An experimental approach. Tectonophysics 489, 1-13.

Higgins, M., 2000. Measurement of crystal size distributions. American Mineralogist 85, $1105-1116$

Krantz, R.W., 1991. Measurements of friction coefficients and cohesion for faulting and fault reactivation in laboratory models using sand and sand mixtures. Tectonophysics 188, $203-$ 207.

Lemrabott, A., Cobbold, P.R., 2010. Physical Modeling of Fluid Overpressure and Compaction During Hydrocarbon Generation in Source Rock of Low Permeability. Search and Discovery Article \#40518. http://www.searchanddiscovery.com.

Liu, L., Bajaj, C., Deasy, J.O., Low, D.A., Ju, T., 2008. Surface reconstruction from nonparallel curve networks. EUROGRAPHICS 2008 27, 2. The eurographics association and Blackwell Publishing Co Ltd. Available at: http://diglib.eg.org/EG/Publications/bookstore/Proc.

Mallet, J.-L., 1992. Discrete smooth interpolation in geometric modeling. Computer-Aided Design 24 (4), 178-191. 
Mallet, J.L., 2002. Geomodeling. Oxford University Press, 613 p.

Mourgues, R., Cobbold, P.R., 2003. Some tectonic consequences of fluid overpressures and seepage forces as demonstrated by sandbox modelling. Tectonophysics 376, 75-97.

Osborne, M.J., Swarbrick, R.E., 1997. Mechanisms for generating overpressure in sedimentary basins: a reevaluation. American Association of Petroleum Geologist Bulletin 81, 1023-1041.

Parnell, J. and Carey, P.F., 1995. Emplacement of bitumen (asphaltite) veins in the Neuquén Basin, Argentina. American Association of Petroleum Geologist Bulletin 79, 1798-1816.

Parnell, J., Honghan, C., Middleton, D., Haggan, T., Carey, P., 2000. Significance of fibrous mineral veins in hydrocarbon migration: fluid inclusion studies. Journal of Geochemical Exploration 69-70, 623-627.

Rodrigues, N., Cobbold, P. R., Løseth, H., 2009. Physical modelling of sand injectites. Tectonophysics 474, 610-632.

Rojas, L., Mpodozis, C., 2006. Geología estructural de la Faja Plegada y Corrida de Tierra del Fuego, Andes Patagónicos Chilenos. 11 Congreso Geológico Chileno, Actas 1, 325-328.

Román-Berdiel, T., 1999. Geometry of granite emplacement in the upper crust: contribution of analogue modelling. In: Castro, A., Fernández, C., Vigneresse, J.L. (Eds.), Understanding Granites: Integrating New and Classical Techniques. Geological Society, London, Special Publication 174, 77-94.

Schellart, W.P., 2000. Shear test results for cohesion and friction coefficients for different materials: scaling implications for their usage in analogue modelling. Tectonophysics 324 , $1-16$.

Swarbrick, R.E., Osborne, M.J., Yardley G.S., 2002. Comparison of overpressure magnitude resulting from the main generating mechanisms. In: Huffman, A.R., Bowers, G.L. (Eds.), Pressure regimes in sedimentary Basins and their Prediction. American Association of Petroleum Geologists Memoir 76, 1-12.

Zanella, A., Cobbold, P.R., Ruffet, G., Rojas, L., (in press). Beef veins and thrust detachments in Early Cretaceous source rocks, foothills of the Magallanes-Austral Basin, southern Chile and Argentina: structural evidence for fluid overpressure during hydrocarbon maturation. Marine and Petroleum Geology. 


\section{Captions to figures and tables}

Figure 1. A. Photograph of the first (small) apparatus. Plastic box $(30 \mathrm{~cm}$ x $20 \mathrm{~cm}$ x $10 \mathrm{~cm})$ with an aluminium baseplate rests on an electric heater. Piston (left) can deform model horizontally. During heating, beeswax microspheres melt. Vertical well (not visible) measures pore fluid pressure at base of model. For description of layers, see Fig. 2. B. Photograph (3D view) of the new (large) apparatus . Outer plastic box $(1 \mathrm{~m} \times 1 \mathrm{~m})$ rests on aluminium table and has three hot plates beneath it. C. 3D view of outer and inner plastic boxes of the new apparatus. Inner box $(77 \mathrm{~cm} \times 75 \mathrm{~cm}$ ) houses models. Piston (top left), driven by two electric motors, can deform model horizontally.

Figure 2. Results of 4 experiments with first apparatus. Graphs show variation with time (in minutes) of temperature (at 3 points, see text for details) and fluid pressure (at base of model) since beginning of each experiment. Photographs show longitudinal sections. Results are for no organic matter and no overall deformation (A. Experiment 11 - Series I); organic matter and no overall deformation (B. Experiment 1 - Series I); organic matter and extensional deformation (C. Experiment 4 - Series I); or organic matter and compressional deformation (D. Experiment 8 - Series I). For Experiment 4, piston was at right and moved outward (to right) at $2.5 \mathrm{~cm} / \mathrm{h}$; whereas, for Experiment 8, piston was at left and moved inward (to right) at $2.5 \mathrm{~cm} / \mathrm{h}$.

Figure 3. Photographs of top surface, Experiment 4 - Series II, (A) before deformation $(t=0)$ and (B) after 450 mins. Five vertical glass tubes (A, top) are for measuring pore fluid pressure (every $5 \mathrm{~cm}$, from bottom to top of source layer). After deformation (B), wax migrated into central horizontal hydraulic fracture, uplifting surface of model. Runnels, visible at the surface, formed by runoff of water during submerging of the model and do not have any effects at depth.

Figure 4. Selection of 8 full-length serial cross-sections, Experiment 4 - Series II (no applied horizontal deformation). For number and position of each section, see key (top left). Wax has migrated upward (and laterally) through pore space, from basal blue source layer and into open horizontal hydraulic fractures, forming sills (white) upon solidifying. At centre of model, sills are most numerous and thick within yellow layer; whereas, near edges of model, 
some sills are visible in blue basal source layer. Large bulges at top of model are above thick sills within source layers. Scale bar is $7 \mathrm{~cm}$ long.

Figure 5. Three views of 3-D model, Experiment 4 - Series II. A. Oblique view of upper surface of layer L1. Colours and contours indicate altitudes (see key at bottom right))., Notice central depression (red or green colours) and surrounding bulges (blue, pink or white). B. Similar view of upper surface, layer L2, showing central bulge (white). C. Cross-section of centre of model and adjacent views of three upper surfaces (layers L1 to L3). Large wax body (tan, with white contour) is immediately beneath bulges (at top L2 and top L3) and at centre of annular lateral depression (at top L3).

Figure 6. Three views of main wax body, Experiment 4 - Series II. A. Oblique photograph of upper surface and cross sections, after removal of surrounding silica powder. In its original position, base of body was gently dipping (see Fig. 6C). B. Oblique view (3D model) after gOcad reconstruction (model 1, small parts disconnected, see Appendix). By comparison with A, notice that many second-order deflections are missing. C. New cross-section of entire model (including layer boundaries). For line of section, see B. Main wax body appears to root locally into top of layer L1 (centre right) and to spread elsewhere within layer L2 (as in true sections, Fig. 4).

Figure 7. Photographs of top surface, Experiment 5 - Series II (compressional deformation), before deformation $(\mathrm{A}, \mathrm{t}=0)$ and at two later stages $(\mathrm{B}, \mathrm{t}=30 \mathrm{~min} ; \mathrm{C}, \mathrm{t}=170 \mathrm{~min})$. Before melting of wax and consequent generation of fluid overpressure (until t $=30 \mathrm{~min}, \mathrm{~B}$ ), compressional deformation resulted in formation of a high-angle prism, next to piston and deformation front was straight. Subsequently the deformation front migrated more rapidly away from piston and began to curve, migrating fastest in centre of model, where temperature was highest (see text for details).

Figure 8. Selection of 8 full-length serial cross-sections (13 to 22), Experiment 5 - Series II (compressional deformation). Piston (at left) has moved inward (to right). From bottom to top, black layer is of sand, yellow and blue layers are source layers (equal initial volumes of wax microspheres and of silica powder); and white layer is of pure silica powder. Near piston (left) fore thrusts and back thrusts (thick-skinned deformation) were responsible for formation 
of a high-angle wedge, affecting all layers; whereas further away (right), deformation was thin-skinned, above detachment at base of yellow layer, producing low-angle wedge in uppermost three layers. Thrust offsets decreased away from piston. Some imbricate zones formed in source layers. Small wax bodies (white) also formed, especially in yellow layer. Scale bar (bottom right) is $7 \mathrm{~cm}$ long.

Figure 9. Close-up views of two models, illustrating structural details. A. Central part of cross-section number 16, Experiment 4 - Series II (no applied horizontal deformation). Main wax sill (white) is clearly visible (centre) and attests to tensile opening (arrows) of horizontal hydraulic fracture. Upward bulging of white and yellow layers corresponds to opening of fracture. Basal blue layer has compacted, due to collapse of solid framework, as wax melted and migrated upwards. However, area of compaction is wider than length of main wax body. B. Part of model near piston, after horizontal shortening (Experiment 5 - Series II). Deformation is thick-skinned, near piston (left) and thin-skinned, away from piston (right). Flat-lying detachment is visible at base of yellow source layer. This layer also contains an imbricate thrust zone and several gently dipping wax bodies, which we interpret as having formed during horizontal simple shear (top to right).

Table 1. Properties of the modelling materials. A. Properties of beeswax microspheres, as used in this study. B. Mechanical properties of dry silica powder (from Rodrigues et al., 2009).

Table 2. Data for Experiment 4 - Series II (according to gOcad 3D modeller). A. Compaction data. B. Volume changes. C. Volumes of wax bodies. 
Physical modelling of chemical compaction, overpressure development, hydraulic fracturing and thrust detachments in organic-rich source rock

\section{Highlights}

1. We have developed physical models to investigate the origin of fluid overpressure.

2. We used a mixture of beeswax microspheres and silica powder as source material.

3. The melting of wax led to fluid overpressure and hydraulic fracturing.

4. During horizontal shortening, detachments appeared at the base of the source layer. 
Table 1A. Beeswax microspheres

\begin{tabular}{lcccccccc}
\hline $\begin{array}{l}\text { Material } \\
\mu \mathrm{m}\end{array}$ & $\begin{array}{c}\text { Grain size, Melting point, } \\
{ }^{\circ} \mathrm{C}\end{array}$ & $\begin{array}{c}\text { Density } \\
\left(\text { solid), }{\mathrm{g} . \mathrm{cm}^{-3}}^{-3}\right.\end{array}$ & $\begin{array}{c}\text { Density (liquid), } \\
\mathrm{g} \cdot \mathrm{cm}^{-3}\end{array}$ & $\begin{array}{c}\text { Viscosity } \\
\text { (liquid), Pa.s }\end{array}$ & $\begin{array}{c}\text { Thermal } \\
\text { expansion } \\
\text { coefficient, } \\
. \mathrm{C}^{-1}\end{array}$ & $\begin{array}{c}\text { Thermal } \\
\text { conductivit } \\
\mathrm{y}, \mathrm{W} \cdot \mathrm{m}^{-1} \cdot \mathrm{K}^{-} \\
1\end{array}$ & $\begin{array}{c}\text { Latent heat } \\
\text { of fusion, } \\
\mathrm{J} \cdot \mathrm{g}^{-1}\end{array}$ \\
\hline $\begin{array}{l}\text { microsphere } \\
\mathrm{s}\end{array}$ & $\approx 1000$ & $\approx 62-64$ & $0.95\left(\right.$ at $\left.20^{\circ} \mathrm{C}\right)$ & $0.82\left(\right.$ at $\left.80^{\circ} \mathrm{C}\right)$ & $14 \times 10^{-3}\left(\right.$ at $\left.80^{\circ} \mathrm{C}\right)$ & $350 \times 10^{-6}$ & 0.4 & 175.8 \\
\hline
\end{tabular}

Table 1B. Silica powder

\begin{tabular}{lccccccccc}
\hline Material & Variety & Roughness & Grain size, $\mu \mathrm{m}$ & $\mathrm{d} 10, \mu \mathrm{m}$ & $\mathrm{d} 50, \mu \mathrm{m}$ & $\mathrm{d} 90, \mu \mathrm{m}$ & $\begin{array}{r}\text { Particle } \\
\text { density, } \\
\text { g.cm }{ }^{3}\end{array}$ & $\begin{array}{c}\text { Bulk } \\
\text { density, } \\
\text { g.cm } \mathrm{cm}^{-3}\end{array}$ & $\begin{array}{c}\text { Permeabilit } \\
\text { y to water, } \\
\mathrm{m}^{2} \cdot \mathrm{Pa}^{-1} \cdot \mathrm{s}^{-1}\end{array}$ \\
\hline $\begin{array}{l}\text { Silica } \\
\text { powder }\end{array}$ & $\begin{array}{c}\text { Millisil } \\
\text { C4 }\end{array}$ & Angular & $0-150$ & 177 & 64 & 8.8 & 2.65 & 1.34 & $8.00 \times 10^{-8}$ \\
\hline
\end{tabular}




\begin{tabular}{cc}
\hline $\begin{array}{c}\text { Intrinsic } \\
\text { permeabilit } \\
\mathrm{y}, \mathrm{m}^{2}\end{array}$ & $\begin{array}{c}\text { Intrinsic } \\
\text { pemeabilit } \\
\mathrm{y}, \text { Darcy }\end{array}$ \\
\hline $1.6 \times 10^{-12}$ & 1.621 \\
\hline
\end{tabular}


Table 2A. Compaction data for Experiment 4 - Series II

\begin{tabular}{lccccc}
\hline Layer & Initial wax & $\begin{array}{c}\text { Intrusion or } \\
\text { melting }\end{array}$ & $\begin{array}{c}\text { Initial volume, } \\
\mathrm{cm}^{3}\end{array}$ & $\begin{array}{c}\text { Final volume, } \\
\mathrm{cm}^{3}\end{array}$ & $\begin{array}{c}\text { Compaction, } \\
\%\end{array}$ \\
\hline $\mathrm{L} 3$ & No & No & 8662 & 6944 & 19.8 \\
\hline L1+L2 & Yes & Yes & 11550 & 11394 & 1.4 \\
\hline
\end{tabular}

Table 2B. Volume changes in Experiment 4 - Series II

\begin{tabular}{lcccc}
\hline Layer & $\begin{array}{c}\text { Initial } \\
\text { volume, } \mathrm{cm}^{3}\end{array}$ & $\begin{array}{c}\text { Volume after } \\
\text { compaction, } \\
\mathrm{cm}^{3}\end{array}$ & $\begin{array}{c}\text { Final volume, } \\
\mathrm{cm}^{3}\end{array}$ & $\begin{array}{c}\text { Volume } \\
\text { change, } \mathrm{cm}^{3}\end{array}$ \\
\hline $\mathrm{L} 2$ & 5775 & 5697 & 6201 & +504 (gain) \\
\hline $\mathrm{L} 1 \mathrm{5}$ & 5775 & 5697 & 5193 & -504 (loss) \\
\hline
\end{tabular}

Table 2C. Volumes of wax bodies in Experiment 4 - Series II

\begin{tabular}{lccc}
\hline & $\begin{array}{c}\text { Total } \\
\text { volume, } \mathrm{cm}^{3}\end{array}$ & $\begin{array}{c}\text { Volume in L1, } \\
\mathrm{cm}^{3}\end{array}$ & $\begin{array}{c}\text { Volume in L2, } \\
\mathrm{cm}^{3}\end{array}$ \\
\hline Model 1 & 500 & 215 & 285 \\
\hline Model 2 & 810 & 380 & 430 \\
\hline
\end{tabular}



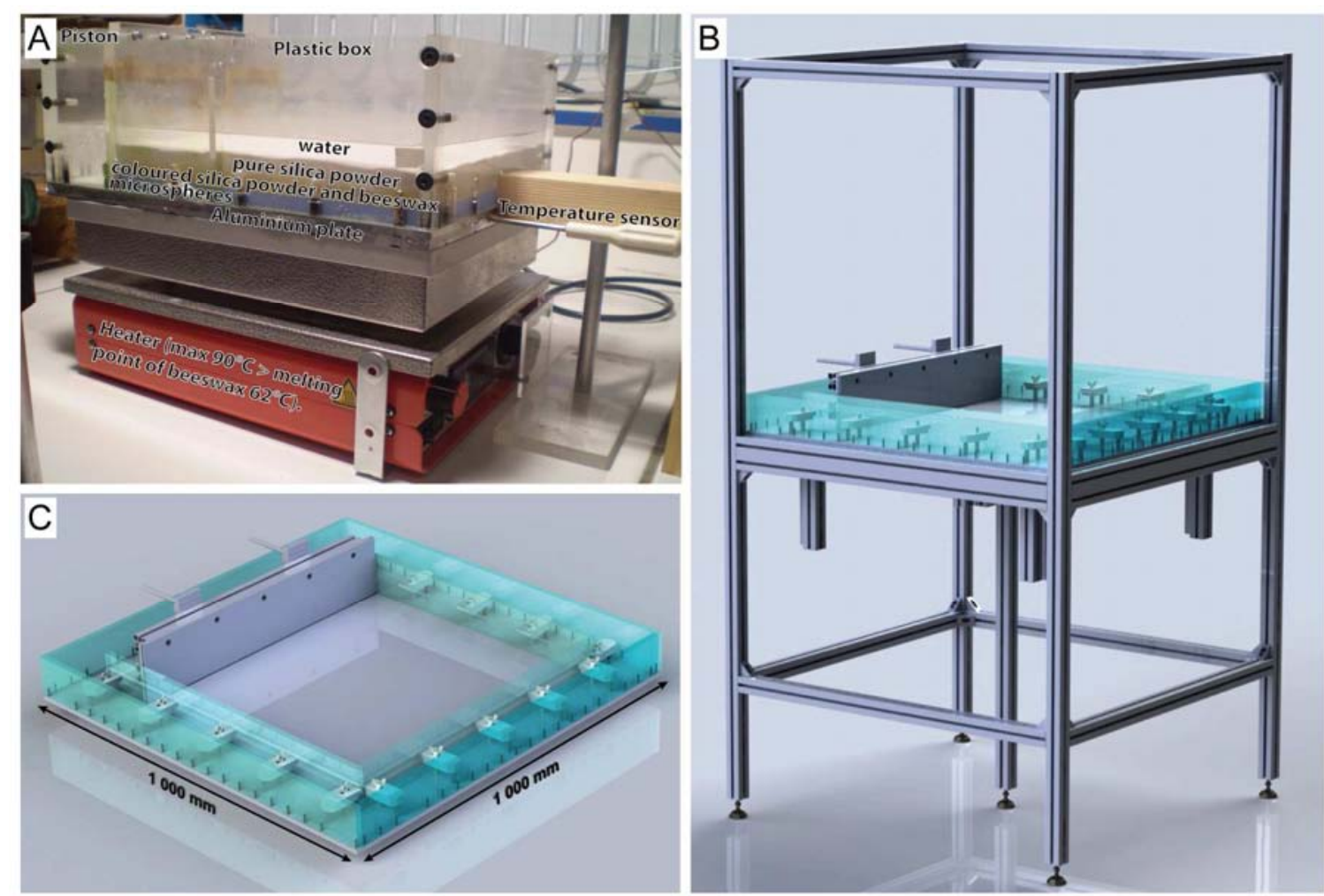


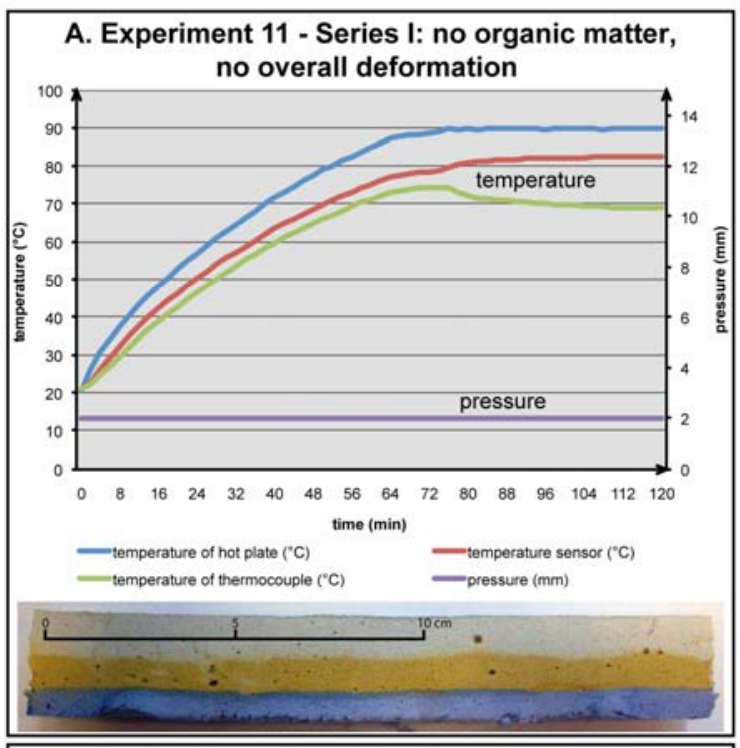

C. Experiment 4 - Series I: organic matter, extensional deformation

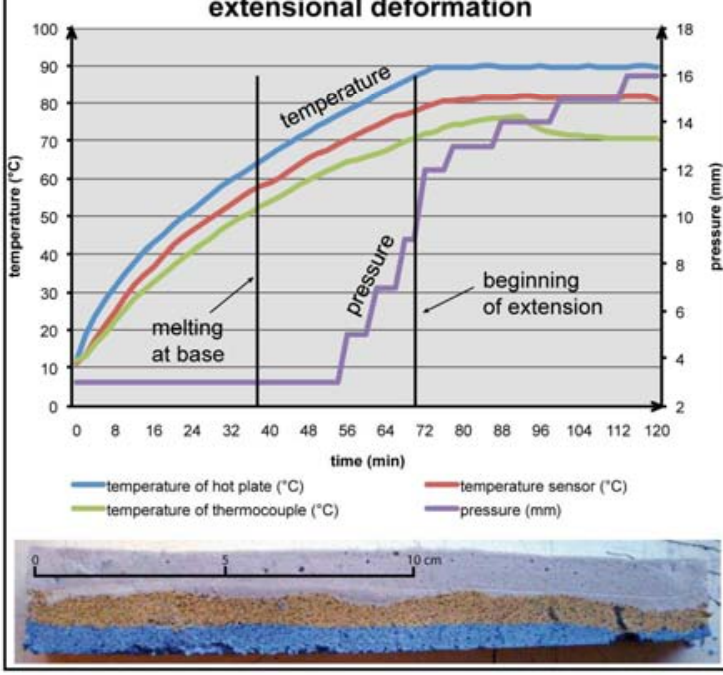

B. Experiment 1 - Series I: organic matter, no overall deformation

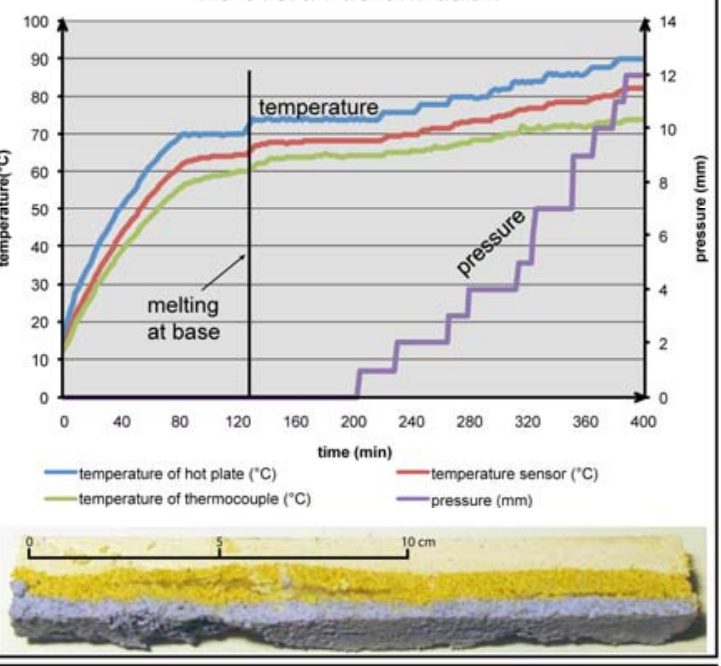

D. Experiment 8 - Series I: organic matter, compressional deformation

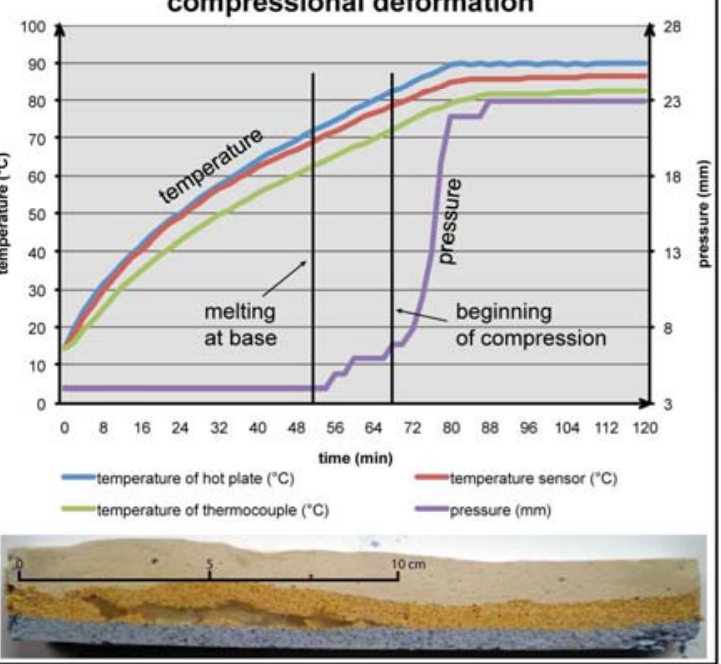



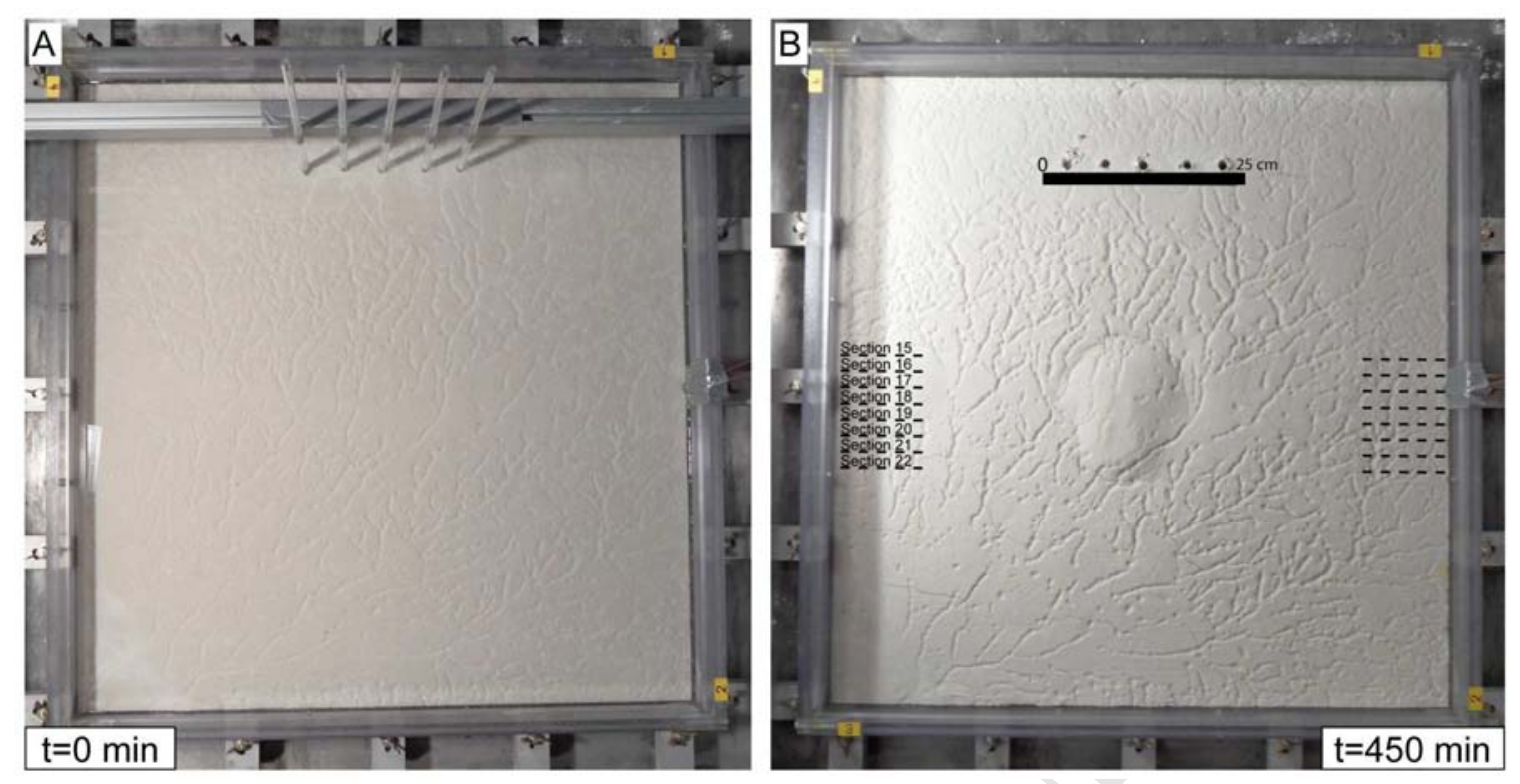

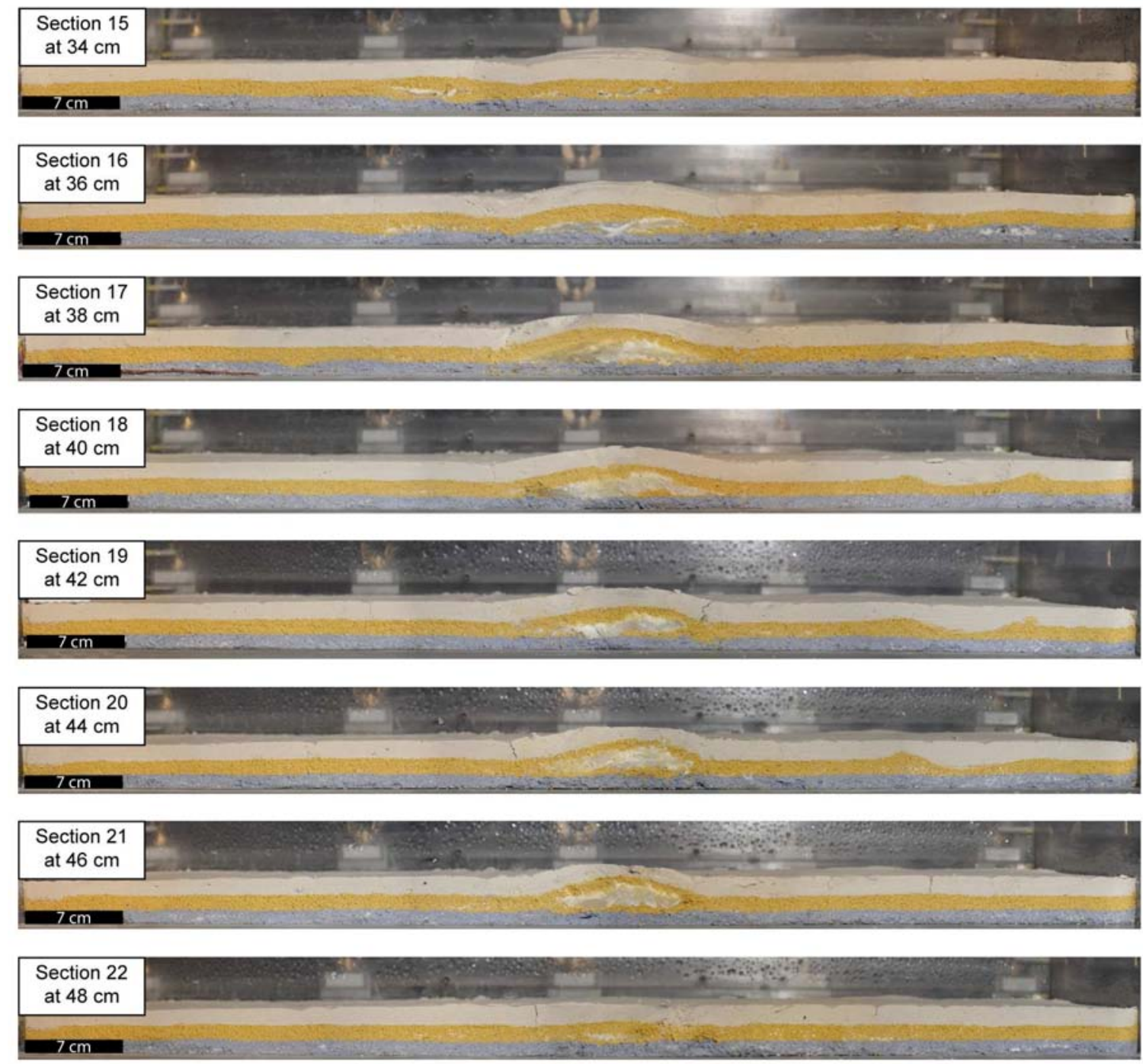

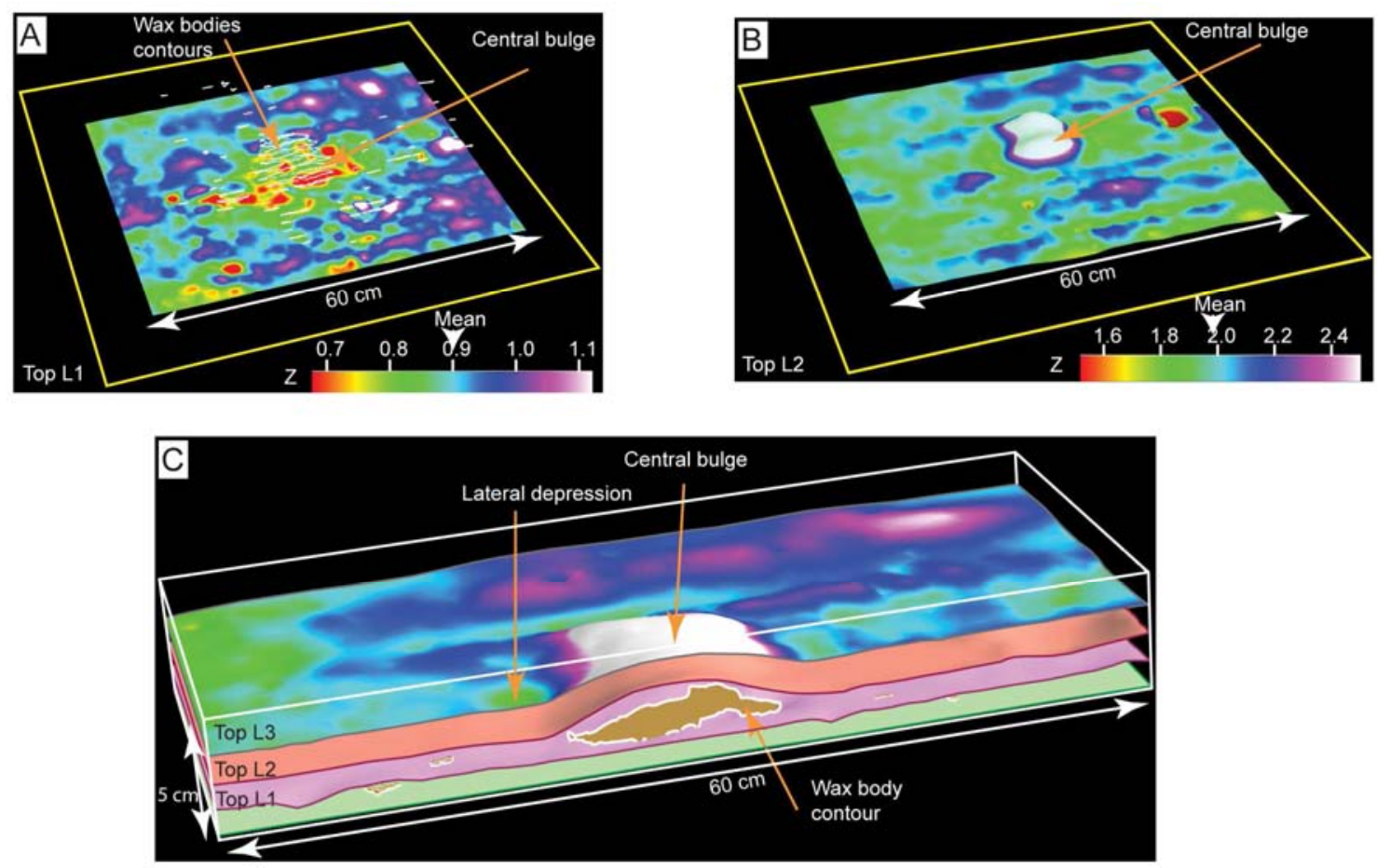

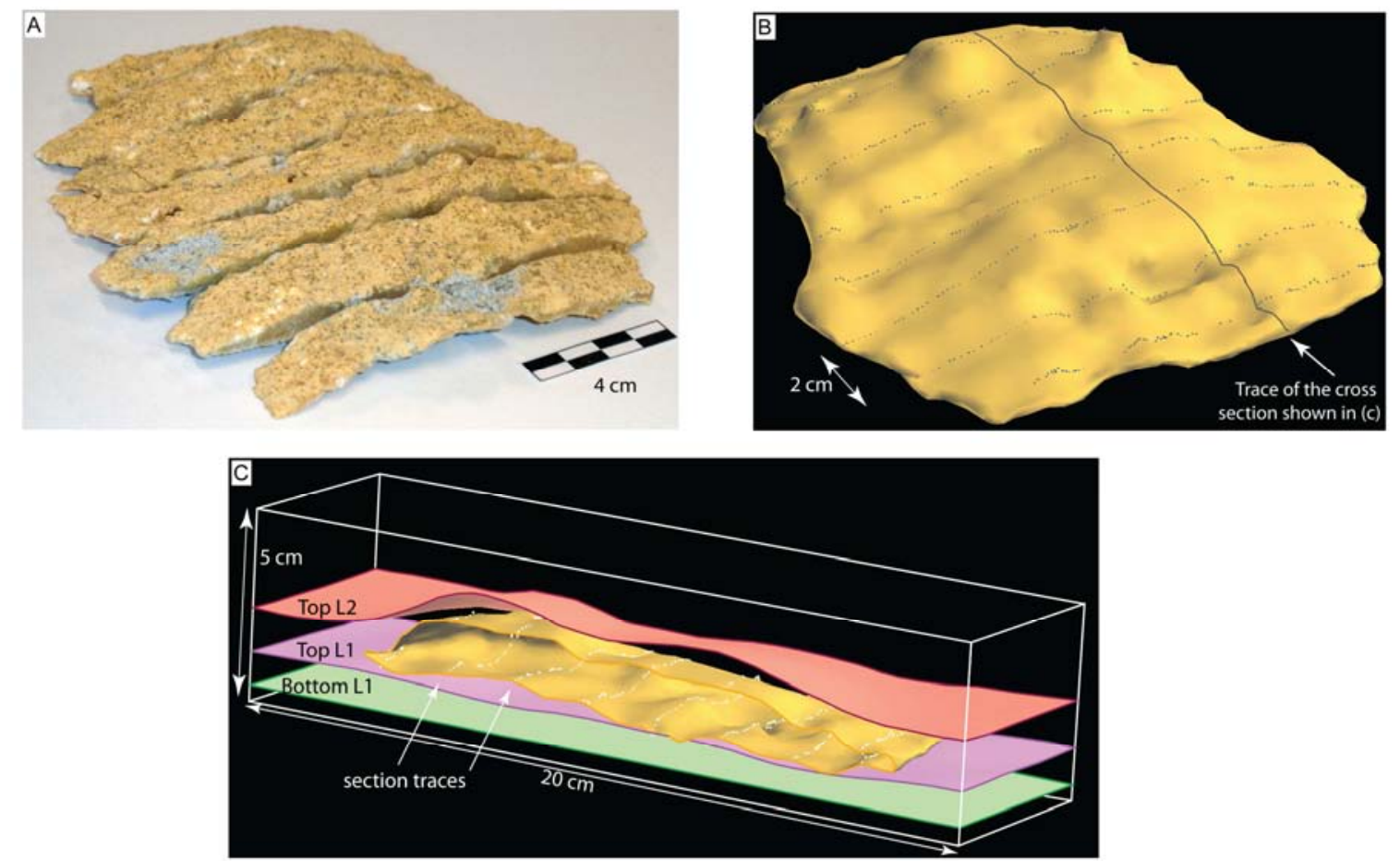

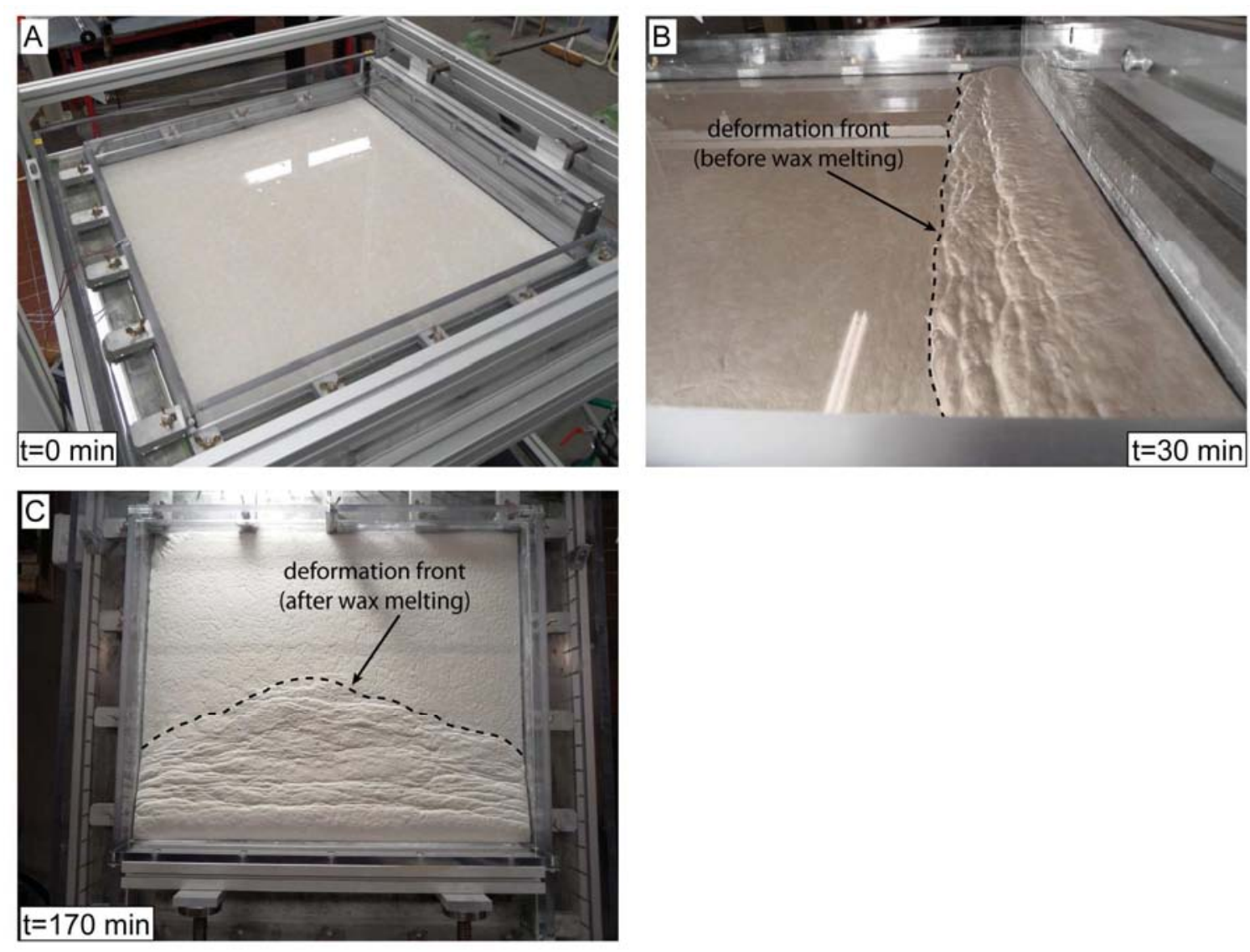

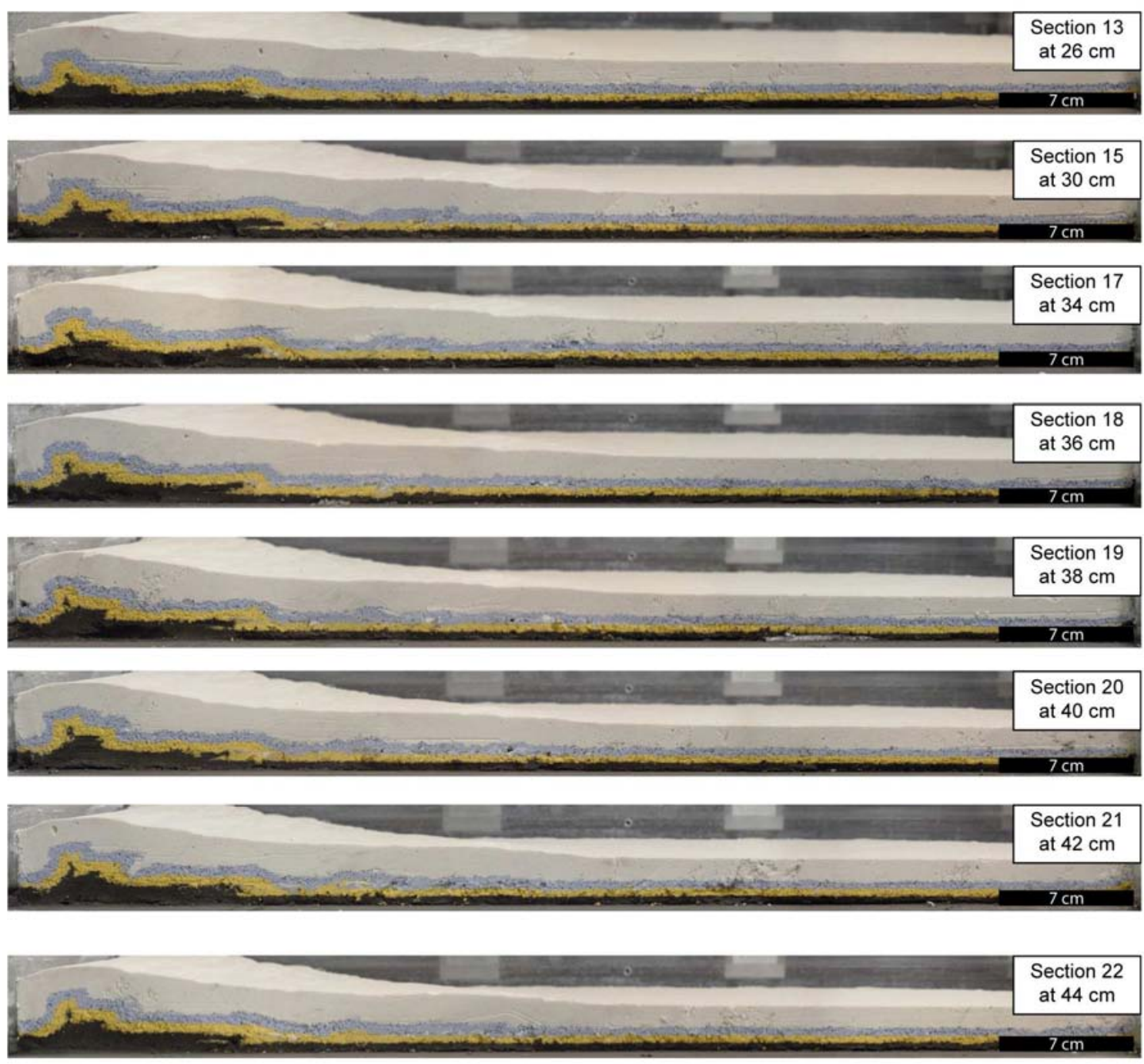

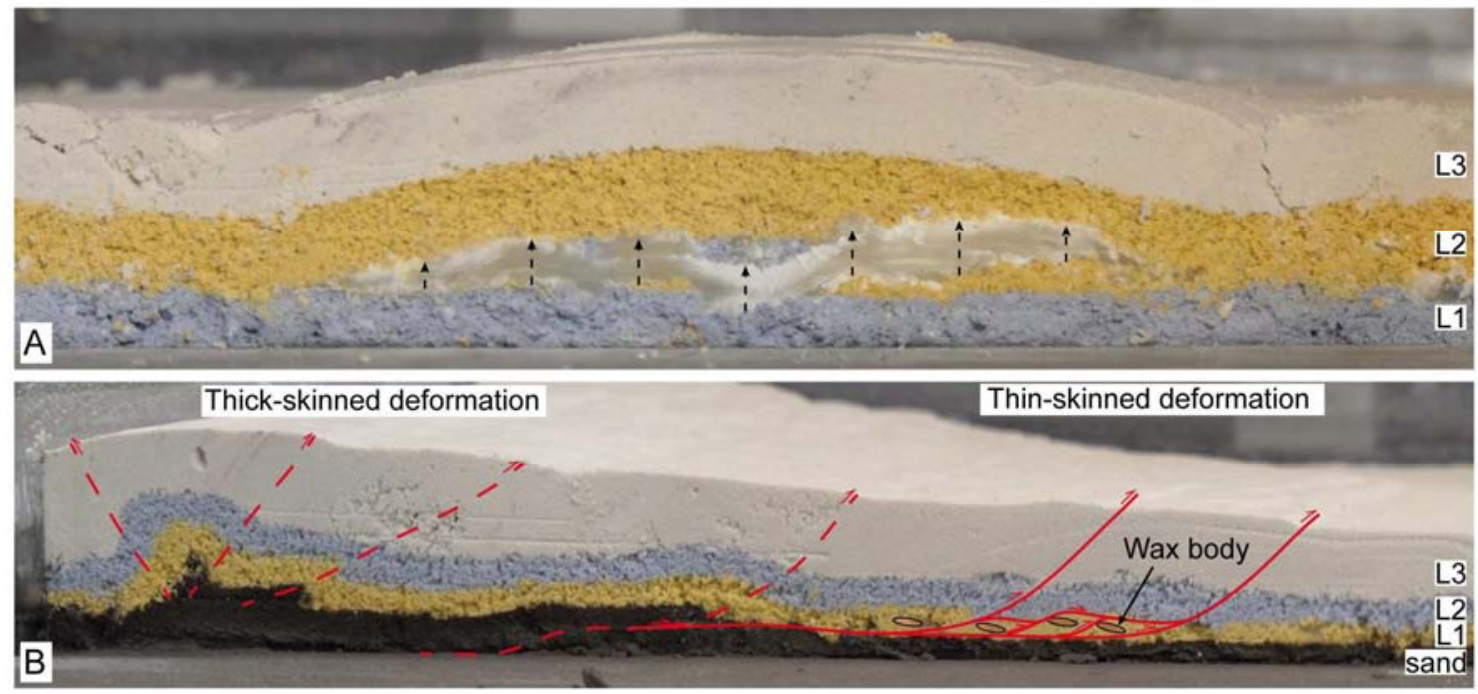